\title{
SPANISH LEGISLATION AND IB PYP LANGUAGE POLICY
} DEVELOPMENT

\section{LEGISLACIÓN ESPAÑOLA Y DESARROLLO DE POLÍTICAS DEL PEP DEL IB}

\author{
Veronica Steffen \\ Daniel Prieto \\ Ángeles Bueno
}

\section{Abstract}

Given the growth of and interest in International Baccalaureate (IB) programmes in Spain, schools looking for approval to implement any of its programmes are being met with the challenge of policy development to meet the requirements for authorization. This paper will look at Spanish legislation and the supports or challenges it offers when trying to meet the needs that face schools looking towards IB Primary Years Programme (PYP) authorization. As schools already authorized will have used the 2014 version of the IB Programme Standards and Practices, this paper will focus on the development of language policy in this version as well as the 2018 versions to support these schools as they move to the next stage or new schools starting under this newer version. A comparative look at Spanish legislation that may have influenced past decisions and current legislation that will influence future decisions will summarize the support mechanisms for meeting the language policy requirement.

Key words: Spanish education legislation, language policy, IB Primary Years Programme authorization, IB Standards and Practices, comparative education

\section{RESUMEN}

Dado el crecimiento y el interés en los programas de Bachillerato Internacional (IB) en España, los colegios que buscan la aprobación para implementar cualquiera de sus programas se enfrentan al desafío del desarrollo de políticas para cumplir con los requisitos de autorización. Este documento analizará la legislación española y los apoyos o desafíos que ofrece al tratar de satisfacer las necesidades que enfrentan los colegios que buscan la autorización del Programa de la Escuela Primaria (PEP) del IB. Dado que los colegios ya autorizados habrán utilizado la versión 2014 de los Estándares y Prácticas del Programa del IB, este documento se centrará en el desarrollo de la política lingüística en esta versión, así como en la versión 2018 para ayudar a estos colegios a avanzar a la siguiente etapa o a las nuevas escuelas a partir de esta nueva versión. Una mirada comparativa a la legislación española que puede haber influido en decisiones pasadas y la legislación actual que influirá en decisiones futuras resumirá los mecanismos de apoyo para cumplir con el requisito de la política lingüística.

Palabras clave: legislación educativa española, política lingüística, autorización del Programa de la Escuela Primaria del IB, Estándares y Prícticas del Programa del IB, educación comparada

Fecha de recepción: 01 de octubre de 2020.

Fecha de aceptación: 16 de diciembre de 2020. 


\section{INTRODUCTION}

Principles underlying the education of students are found in education policy. These are influenced by the evolution of societies and cultures leading to continuous revision and debate. In general, policies ensure compliance with laws through statements of standards and rules in a variety of scenarios. These guiding principles map the operations for and directions of organizations, steering decision making and streamlining procedures and processes related to employees and other stakeholders. Stakeholders in education policy may include students, parents, teachers, and school administrators. In the IB the collaborative development of a school's language policy is meant to ensure input by these stakeholders. Depending on the educational institution, these may also include elected and non-elected officials, professors, and schools of education, as well as businesses because of work force needs.

Many of the first policies in education were related to religious goals along with learning skills and fundamental knowledge, many related to language learning. Though most stakeholders still agree that students should learn some fundamental skills and knowledge, disagreement exists as to the methods used to teach subjects, including how to teach languages. More recently participating in the global economy is being perceived as a necessary goal in education, and language learning a key aspect in supporting involvement. As such, education policies can pit stakeholders against each other. Local and national governmental control over aspects of education, and most recently, language learning in Spain, is also a factor of this tension. These tensions lead to variation among school systems and programmes offered.

The Oxford Dictionary Lexico (n.d.) defines policy as 'a course or principle of action adopted or proposed by an organization or individual.' According to the Online Etymology Dictionary (n.d.), the origin of the word 'policy' in relation to management is recorded in French in relation to civil administration or political organization. Interestingly, in relation to insurance, the Greek root 'apodexis' addresses 'proof and 'deiknynai' 'to show'. In this article, both ideas are used where courses or principles of action proposed in Spanish legislation are meant to show or prove adherence to the requirements of the International Baccalaureate (IB) and its Primary Years Programme (PYP) to develop and implement a language policy that reflects the organization and programmes philosophy and objectives.

\section{A BRIEF OVERVIEW OF LANGUAGE-RELATED EDUCATION POLICY}

By putting policy into writing, understanding the 'why' of actions can be more easily drafted, agreed upon, and shared. Today, as in the past, most major education policies address issues that answer the following seven questions (Education policy in the United States, n.d.) which are both transferrable to other national contexts and pervasive over time:

1. Who should be educated and by whom?

2. What should be taught, and who decides this?

3. Where and when should students be educated?

4. Who is responsible for the delivery of education?

5. How much should education cost and who should pay for it?

6. What are the standards for measuring success?

7. What should and can be done to correct failure? 


\subsection{HISTORICAL BEGINNINGS OF EDUCATION POLICY}

The basis of much educational thought in Europe followed from the Romans, where the beginnings of primary education was found in language learning, especially Latin and Greek, in specialized grammar schools. Although governmental administration changed in southern Europe with Visigoth invasions in the fifth century, the Roman Catholic religion continued to play an important role in education becoming more formalized with the establishment of monastic schools focused on spreading Christianity through reading the Bible. The 8th century brought Islamic control to the Iberian Peninsula, and Dozy (1881, in González, 2006) defines the unordinary education of one Muslim as knowing classic poems by heart and being able to tell old war stories. Jews at the time had their own internal laws and educational systems though no matter what the religion, learning was tied to religious centres.

In the 15th century, humanism spread throughout Europe, though these reforms were curtailed in Spain. Support for public schooling began to grow though, during the 17th and 18th centuries, completely funded publicly schools were scarce around the world. Curricula was still carried over from Roman times where reading, especially the Bible, was still perceived as vital to education. Educators like Rousseau (National Geographic, 2013) or Feijoo (Rodríguez Pardo, 2008) saw education as the main instrument for bringing about social reform, and political leaders started to view literacy as necessary for voter's participation in democracy. Still, at this time, nothing approaching standard curriculum or a unified theory of education existed.

\subsection{EDUCATION POLICY AND THE INDUSTRIAL REVOLUTION}

The 1812 Spanish Constitution made education a national responsibility, and early 19th century Spanish liberal governments attempted to loosen restrictions to provide public education. First attempts failed, and it was not until the mid-19th century that efforts began to prevail with the passage of legislation for basic educational reform. As part of free public education in the United States (US), Mann's “Common School Movement" (Warder, 2001-2008) attempted to move schools toward the professional delivery of a broader curriculum publishing expectations and issues in The Common School Journal.

The second half of the 19th century in Spain saw conflict between liberals' democratic constitution vs. conservatives' monarchy restoration affecting academic freedom and views toward religion in schools. Education was obligatory for children under ten from 1880 in Britain's public schools. Standard curriculum up to $8^{\text {th }}$ grade was prescribed by Ministries of Education in North America. School policy still was not documented in schools though one room schoolhouses in North America often posted rules provided by Boards of Education.

\subsection{EDUCATION POLICY IN THE $20^{\text {TH }}$ CENTURY}

In Spain, the 1923 military uprising silenced many Spanish intellectuals, but the Constitution proposed by the 1931 Second Republic included academic freedom, non-religious instruction, and free compulsory primary education in its educational reforms. These failed with the 1939 rise of Nationalist forces where status of obligatory Catholic religious instruction returned (StateUniversity.com Education Encyclopedia, n.d.). The early part of the 20th Century saw progressive movements elsewhere in the world using education to bring about social reform. John Dewey led others in challenging the creation of dutiful citizens and cultural uniformity moving towards experiential learning, critical thinking, and a focus on the individual (John Dewey Project 
on Progressive Education, 2003). Though radical at the time, these movements continue to inspire much of IB education.

Policy for primary education arose in the late 1950s when national governments increased their role in its development. The US National Defense Education Act (NDEA) included amongst others "improvement of foreign language instruction" (United States Dept of Education, 2017). In 1960, Spain signed the convention as a member of the newly established Organisation for Economic Co-operation and Development (OECD) (Spanish Ministry of Education and Science, 2007) whose purpose was the promotion of policy development for people's economic and social well-being. Spain's 1970 General Law on Education (LGE) finally provided compulsory education for children to 14 years old. The 1978 Spanish Constitution brought further educational reform with the Organic Law of 1980 (LOECE). In 1986, Spain joined the European Union (EU), bringing with it greater appreciation for cultural and linguistic diversity. During this time, OECD members requested educational inputs, going beyond the original interpretative outputs, in the form of a framework based on theories to define explicit skills, knowledge, and competences. In 1997, the Definition and Selection of Competencies Project (DeSeCo) (Rychen \& Salganik, 2001) was founded to provide for this need.

\subsection{CURRENT STATE OF EDUCATION POLICY}

Two major 21st century policy issues are school choice and academic performance. Aud (2007) notes that Friedman's "School Choice" movement called for both leading to greater accountability and discussions of educational standards, what they should encompass, and whether they should be made common. The US 2008 Common Core State Standards Initiative outlined quantifiable benchmarks in English language learning, amongst others, at each grade level followed by the 2009 Race to the Top (Race to the Top, n.d.) initiative which measured states' progress against targets they set for themselves. Spain followed suit by allowing greater autonomy in Autonomous Communities (CCAA) and educational centres.

Although the key competences identified in the DeSeCo Project document continue to guide curriculum development, the last 20 years have presented sundry changes in Spanish governance. Unfortunately, with every change, schools are challenged to implement newly proposed laws or changes to ones already in place. These have had schools racing to in circles rather than sustaining educational continuity knowing that these may once again vary depending on the political climate in the country.

\section{IB PROGRAMME STANDARDS AND PRACTICES}

Knight (2020) suggests that parents consider authorization of given programmes as one criterion when deciding in which school to enrol their children. Authorization is a voluntary decision encouraging continuous improvement and self-reflection. It gives a school approval for the delivery of a programme after checking that the school, within its own local and national legal context, has the capacity to deliver and ensure student learning within that programme. In IB authorization processes, schools must be aligned with the educational values of the organization that are found in its Programme Standards and Practices (PSP) $(2014$; 2018) document. This acts as the foundation on which teaching and learning occur, and the related policies act as supports for this foundation by setting written guidelines to follow. 


\subsection{PSP 2014}

This document is organized into three broad sections:
A. Philosophy,
B. Organization and
C. Curriculum.

In Section A Philosophy, schools must align their beliefs and values with those of the IB.

Section B is subdivided into two parts. B1 sees that the school's leadership and structure support IB programme implementation and B2 that resources and support systems in the school do the same.

Section C is subdivided into four sections. C1 addresses collaborative planning and reflection, C2 the school's written curriculum, C3 teaching and learning in the school, and C4 assessment, where these four areas support IB programme implementation and reflect IB philosophy.

\subsection{PSP 2018}

The revised 2018 version is organized into four sections which have been set in a triangular framework which sets learning at the centre (See Figure 1). The sections are:
01 Purpose,
02 Environment,
03 Culture and
04 Learning.

Purpose addresses how schools and their communities embrace, foster, and articulate the IB philosophy.

Environment looks at the provision of essential structures, systems, and resources.

Culture deals with the use of rules, both written and unwritten, which define how a school functions to develop a positive school culture.

Learning uncovers the efficacy of education in a centre through curriculum designs that are coherent, the promotion of lifelong learning, and approaches to teaching and assessment that ensure learning experiences are meaningful and information gathered informs and drives the learning.

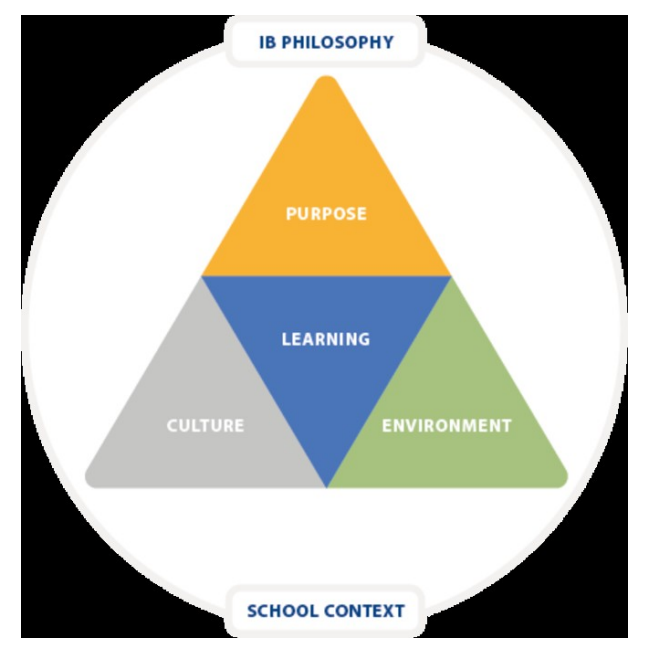

Figure 1: Standards and Practices Framework

Fuente: International Baccalaureate Organization (2018) 
It should be noted that in both versions the practices may be further subdivided into more specific requirements which are only meant for a given IB programme in the 2014 version, and in the 2018 version, these requirements may be further subdivided into programme specifications.

Although many schools underwent PYP authorization using the 2014 version of the IB PSP, the revised 2018 version will be used as those schools move forward with PYP implementation and for new schools being authorized. The language policy, as a requirement for authorization, will be looked at in relation to the expectations of both versions.

\section{EDUCATION IN SPANISH LEGISLATION}

Keeping in mind the previously outlined changes in education history which have impacted on policy and the current state of education, this section summarizes specific Spanish education legislation from 1980 after the implementation of the Spanish constitution.

\subsection{SPANISH LEGISLATION IN THE 80s}

The short-lived Organic Law of 1980 (LOECE) set a basis for the nature and structure of Spanish education as found in the 1990 Organic Law (LOGSE) and subsequent 1995 Organic Law on Participation (LOPEG).

The 1985 Organic Law Regulating the Right to Education (LODE) incorporated freedom of education along with state assisted funding for centers of private and public education. This law guaranteed educational opportunities as a right for all Spanish citizens where they were expected to take on a greater participative role.

\subsection{SPANISH LEGISLATION IN THE 90S}

The 1990 Organic Law on the General Organisation of the Education System (Ley Orgánica de Ordenación General del Sistema Educativo de España - LOGSE) transferred a percentage of educational policy responsibilities from national level to Autonomous Communities (CCAA). What remained at the national level was meant to ensure a common level of learning across Spain by stipulating minimums as well as reiterating mandatory and publicly funded schooling. General and special systems of education were defined providing guidance for special educational needs and socially disadvantaged students. Factors of a quality education were also described, and life-long learning was established as a principle.

The 1995 Organic Law on Participation, Evaluation and Governance of Educational Institutions (Ley Orgánica de Participación, Evaluación y Gobierno - LOPEG) redefined participation of educational communities in school governance. Greater autonomy in educational project design was provided as well as regulation of control by education authorities in inspections, supervision, and evaluation of centres.

\subsection{SPANISH LEGISLATION AT THE TURN OF THE CENTURY}

Although the 2002 Organic Law on Quality in Education (Ley Orgánica de Calidad de la Educación - LOCE) was never implemented, it was guided by principles of a culture of effort, results-oriented educational systems, diversity and quality opportunities for the school community, the importance of the faculty for improved educational quality, and greater school responsibility for achievement. The 2006 Organic Law on Education (Ley Orgánica de Educación - LOE) intended to repeal the LOCE, LOPEG, and LOGSE. The collaboration of all the educational community became pivotal 
in providing quality education. This included student participation and managing diversity. Provisions for training were made in line with European systems to ensure lifelong transitions to employment or other activities. All areas in education were to be made accountable via established mechanisms of evaluation.

Many of the changes in the 2013 Organic Law to Improve Educational Quality (Ley Orgánica de Mejora de Calidad Educativa - LOMCE) addressed secondary schooling. Those related to primary education in general and language in particular included: giving more weight to core government minimums i.e. Spanish language and literature and a first foreign language, Spanish as the mandatory principle language of instruction, introduction of a second foreign language, and the return of religion as an academic subject.

The 2020 Organic Law Modifying the Organic Law on Education (Ley Orgánica de Modificación de la LOE - LOMLOE) reverses much of the LOMCE. Areas addressing primary education in general and language in particular include measures to lower grade repetition including the organization of primary education into three 2-year cycles to achieve objectives during this more extended time where repetition would only be allowed at the end of a cycle and must be supported by an individualized education plan; support for students with learning difficulties; replacement of $6^{\text {th }}$ year primary revalidation with $4^{\text {th }}$ year primary diagnostic testing; respect for the United Nation's (UN) Convention on the Rights of the Child 'specific culture of children' in early childhood; and basing education on the principles of the Universal Design for Learning.

\section{METHODOLOGY AND RESEARCH TOOLS}

The design of this study is non-experimental. A literature review was first carried out for three areas: general education policy history, IB Programme Standards and Practices (PSP), and education-related Spanish Ministry's Official State Bulletins (Boletines Oficiales de Estado - BOE). This was followed with a word search carried out first on the IB PSP documents and later with the same search in the Spanish Ministry's Official State Bulletins. Criteria for the inclusion of words were based on direct links to the focus of the study 'language policy'. As such, the words searched for included 'policy' (política) and language (lengua/ idioma) where derivatives that arose were also considered for their relevance. Derivatives included the plural forms of these words and the derivative 'lenguaje'.

Criteria for the exclusion of words was dependent on relevance to the IB Programme Standards and Practices.

A qualitative approach was then used to compare information derived from the word searches in these documents and draw conclusions about possible connections and supports.

\section{RESULTS}

The results of word searches in the IB PSP documents is followed the those done in the documents of Spanish legislation.

\subsection{IB PSP - 'POLICY’ AND 'LANGUAGE' SEARCH}

Two references to policy in general terms appeared in the 2014 IB PSP document search. 
Table 1: Policy in general - IB Programme Standards and Practices, 2014

\begin{tabular}{|c|c|c|}
\hline $\begin{array}{l}\text { SECTION } \\
\text { STANDARD }\end{array}$ & PRACTICES - REQUIREMENTS & $\begin{array}{l}\text { AUTHORIZATION } \\
\text { EXPECTATION }\end{array}$ \\
\hline $\begin{array}{l}\text { B. } \\
\text { ORGANIZATION } \\
\text { B1: LEADERSHIP } \\
\text { AND } \\
\text { STRUCTURE }\end{array}$ & $\begin{array}{l}\text { B1.5"The school develops and implements } \\
\text { policies and procedures that support the } \\
\text { programme(s) (I.B., 2014, p.3)." }\end{array}$ & in place \\
\hline $\begin{array}{l}\text { C. CURRICULUM } \\
\text { C2: THE } \\
\text { WRITTEN } \\
\text { CURRICULUM }\end{array}$ & $\begin{array}{l}\text { C2.10 "The written curriculum integrates } \\
\text { the policies developed by the school to } \\
\text { support the programme(s) (I.B., } 2014 \text { p.5)." }\end{array}$ & in progress \\
\hline
\end{tabular}

In the revised IB PSP 2018 search, policy is found exclusively in Section 03 Culture including the following reference to policy in general.

Table 2: Policy in general - IB Programme Standards and Practices, 2018

\begin{tabular}{|l|l|}
\hline SECTION & STAND ARD \\
\hline 03 & $\begin{array}{l}\text { 0301: Culture through policy implementation "Schools develop, implement, } \\
\text { communicate and review effective policies that help to create a school } \\
\text { culture in which IB philosophy can thrive. (I.B., } 2018 \text { p.10)" }\end{array}$ \\
\hline
\end{tabular}

In the 2014 PSP, there is one explicit reference to language policy.

Table 3: Language policy references - IB Programme Standards and Practices, 2014

\begin{tabular}{|l|l|l|}
\hline $\begin{array}{l}\text { SECTION } \\
\text { STANDARD }\end{array}$ & PRACTICES - REQUIREMENTS & $\begin{array}{l}\text { AUTHORIZATION } \\
\text { EXPECTATION }\end{array}$ \\
\hline B. & B1.5, B1.5a "The school has developed & in place \\
ORGANIZATION & and implements a language policy & \\
B1: LEADERSHIP & $\begin{array}{l}\text { consistent with IB expectations. (I.B., } \\
\text { AND STRUCTURE }\end{array}$ & \\
\hline
\end{tabular}

It is implicitly understood that the language policy is written to support the implementation of these standards and practices with references to language.

Table 4: Language references - IB Programme Standards and Practices, 2014

\begin{tabular}{|l|l|l|}
\hline $\begin{array}{l}\text { SECTION } \\
\text { STANDARD }\end{array}$ & PRACTICES - REQUIREMENTS & $\begin{array}{l}\text { AUTHORIZATION } \\
\text { EXPECTATION }\end{array}$ \\
\hline A: PHILOSOPHY & $\begin{array}{l}\text { A7, A7a "The school makes provision for } \\
\text { students to learn a language, in addition to } \\
\text { the language of instruction, at least from } \\
\text { the age of seven. Schools with two } \\
\text { languages of instruction are not required } \\
\text { to offer an additional language. (I.B., 2014 } \\
\text { p.7)" }\end{array}$ & in place \\
\hline
\end{tabular}




\begin{tabular}{|c|c|c|}
\hline & $\begin{array}{l}\text { A7, A7b "The school supports mother } \\
\text { tongue and host country language } \\
\text { learning. (I.B., } 2014 \text { p.7)" }\end{array}$ & in progress \\
\hline $\begin{array}{l}\text { C: CURRICULUM } \\
\text { C1: } \\
\text { COLLABORATIVE } \\
\text { PLANNING }\end{array}$ & $\begin{array}{l}\text { C1.8 "Collaborative planning and } \\
\text { reflection recognizes all teachers are } \\
\text { responsible for language development of } \\
\text { students. (I.B., } 2014 \text { p.10)" }\end{array}$ & in progress \\
\hline $\begin{array}{l}\text { C: } \text { CURRICULUM } \\
\text { C3: TEACHING } \\
\text { AND LEARNING }\end{array}$ & $\begin{array}{l}\text { C3.7 "Teaching and learning addresses the } \\
\text { diversity of student language needs, } \\
\text { including those for students learning in a } \\
\text { language(s) other than mother tongue. } \\
\text { (I.B., } 2014 \text { p.12)" } \\
\text { C3.8 "Teaching and learning } \\
\text { demonstrates that all teachers are } \\
\text { responsible for language development of } \\
\text { students. (I.B., } 2014 \text { p.12)" }\end{array}$ & in progress \\
\hline
\end{tabular}

In the 2018 PSP version, the following was found.

Table 5: Language references - IB Programme Standards and Practices, 2018

\begin{tabular}{|c|c|c|}
\hline $\begin{array}{l}\text { SECTION } \\
\text { STAND ARD }\end{array}$ & PRACTICE & REQUIREMENT --SPECIFICATIONS \\
\hline \multirow{4}{*}{$\begin{array}{l}03 \text { CULTURE } \\
0301 \text { CULTURE } \\
\text { THROUGH POLICY } \\
\text { IMPLEMENTATION }\end{array}$} & \multirow{4}{*}{$\begin{array}{l}\text { 0301-04 "The } \\
\text { school } \\
\text { implements, } \\
\text { communicates } \\
\text { and regularly } \\
\text { reviews a } \\
\text { language policy } \\
\text { that helps to } \\
\text { foster } \\
\text { intercultural } \\
\text { understanding } \\
\text { through } \\
\text { communicating } \\
\text { in a variety of } \\
\text { ways in more } \\
\text { than one } \\
\text { language. (I.B., } \\
2018 \text { p.11)" }\end{array}$} & $\begin{array}{l}\text { 0301-04-0100 "The school implements and } \\
\text { reviews a language policy that is aligned with } \\
\text { IB language policy guidelines. (I.B., } 2018 \\
\text { p.11)" }\end{array}$ \\
\hline & & $\begin{array}{l}\text { 0301-04-0200 "The school describes in its } \\
\text { language policy the way that the school } \\
\text { recognizes multilingualism as a fact, a right } \\
\text { and a resource for learning. (I.B., } 2018 \text { p.11)" }\end{array}$ \\
\hline & & $\begin{array}{l}\text { 0301-04-0300 "The school identifies in its } \\
\text { language policy a variety of physical and } \\
\text { virtual resources used to facilitate language } \\
\text { development. (I.B., } 2018 \text { p.11)" }\end{array}$ \\
\hline & & $\begin{array}{l}\text { 0301-04-0400 "The school clearly describes in } \\
\text { its language policy the rights and } \\
\text { responsibilities of all members of the school } \\
\text { community and what constitutes good } \\
\text { practice within the school context. (I.B., } 2018 \\
\text { p.11)" } \\
\text {--0301-04-0411 "The school ensures students } \\
\text { learn a language in addition to the language of } \\
\text { instruction (at least from the age of seven). } \\
\text { Multilingual programmes, where students } \\
\text { learn in at least two languages, can but are not } \\
\text { required to offer additional languages. (I.B., } \\
2018 \text { p.11)" }\end{array}$ \\
\hline
\end{tabular}




\subsection{SPANISH LEGISLATION - 'POLICY’ AND 'LANGUAGE' SEARCH}

The words 'policy' or 'policies' appear in some of the Organic Laws though not specifically in relation to language. Rather, these tend to be either general or references very specific to a given theme. The 1995 Organic Law (LOPEG) had no search results with either word. Because the 2002 Organic Law was never implemented, it will not be addressed in the table of results but it is of interest knowing that educational policies, the current efficacy of policy, teacher policies, and human resource policies were all mentioned in its Statement of Motives.

Table 6: Policy in General - Spanish Organic Laws

\begin{tabular}{|l|l|}
\hline AREA & ARTICLE \\
\hline $\begin{array}{l}\text { LAW: 1985 LODE } \\
\text { Title II Participation in } \\
\text { general programming } \\
\text { of teaching }\end{array}$ & $\begin{array}{l}\text { 28. CCAA education counselors meet as necessary to coordinate } \\
\text { education policy }\end{array}$ \\
\hline $\begin{array}{l}\text { LAW: 1990 LOGSE } \\
\text { Preamble }\end{array}$ & $\begin{array}{l}\text { compensatory actions in policy, scholarship, and study aid policy } \\
\text { to reduce social inequality, policy for adults, and integrative } \\
\text { treatment of special education }\end{array}$ \\
\hline $\begin{array}{l}\text { Title V Compensation } \\
\text { for Inequalities in }\end{array}$ & $\begin{array}{l}\text { 63. compensatory education policies reinforce education system } \\
\text { action to avoid inequalities via opportunities to share and } \\
\text { collaborate } \\
\text { 66. compensatory policies in special and adult education } \\
\text { 67. government proposals of specific programs to CCAA to } \\
\text { achieve objectives of compensatory education policy }\end{array}$ \\
\hline
\end{tabular}

\begin{tabular}{|l|l|}
\hline $\begin{array}{l}L A W: \text { 2006 LOE } \\
\text { Preamble }\end{array}$ & $\begin{array}{l}\text { development of supra-community educational policies: } \\
\text { combining national and regional regulations through new } \\
\text { cooperation mechanisms }\end{array}$ \\
\hline $\begin{array}{l}\text { Preliminary Title } \\
\text { Chapter I Principles } \\
\text { and purposes of } \\
\text { education }\end{array}$ & $\begin{array}{l}\text { 1.a. defining, applying, evaluating educational policies at national } \\
\text { and CCAA levels } \\
\text { 1.b. local business and schools plan and implement educational } \\
\text { policy }\end{array}$ \\
\hline $\begin{array}{l}\text { Chapter IV } \\
\text { Cooperation between } \\
\text { educational } \\
\text { administrations }\end{array}$ & \begin{tabular}{l} 
7. coordination of educational policy \\
\hline $\begin{array}{l}\text { Title I Teaching and its } \\
\text { Distribution } \\
\text { Chapter I Early } \\
\text { Childhood Education }\end{array}$
\end{tabular} \\
$\begin{array}{l}\text { Title II Equity in } \\
\text { Education } \\
\text { Chapter II }\end{array}$ & first Early Years Education cycle public places for students in \\
$\begin{array}{l}\text { Compensation for } \\
\text { education inequalities }\end{array}$ & \\
\hline $\begin{array}{l}\text { Title VI Evaluation of } \\
\text { the educational system }\end{array}$ & 140. evaluation purpose-guiding educational policy \\
\hline
\end{tabular}




\begin{tabular}{|l|l|}
\hline $\begin{array}{l}\text { LAW: } 2013 \text { LOMCE } \\
\text { Preamble VIII }\end{array}$ & $\begin{array}{l}\text { external exams used as educational and diagnostic measures to } \\
\text { improve administrative policies }\end{array}$ \\
\hline $\begin{array}{l}\text { LAW: } 2020 \\
\text { LOMLOE } \\
\begin{array}{l}\text { Fourth objective } \\
\text { (Agenda 2030) }\end{array}\end{array}$ & $\begin{array}{l}\text { incorporating a more stabilized education system as a } \\
\text { foundation of knowledge policies linked to other social policies } \\
\text { including those related to equality, health, diversity, } \\
\text { employment, and digital rights }\end{array}$ \\
\hline
\end{tabular}

As the 2002 Organic Law (LOCE) was never implemented, it will not be addressed.

Table 7: Language references - Spanish Organic Laws

\begin{tabular}{|c|c|}
\hline $\begin{array}{l}L A W \\
A R E A\end{array}$ & ARTICLE \\
\hline $\begin{array}{l}\text { LAW: } 1980 \\
\text { (LOECE) } \\
\text { Title IV Rights and } \\
\text { responsibilities }\end{array}$ & $\begin{array}{l}\text { 31. students will not be discriminated against for admission to } \\
\text { schools for language reasons }\end{array}$ \\
\hline$L A W: 1985$ LODE & no language references \\
\hline $\begin{array}{l}\text { LAW: } 1990 \\
\text { LOGSE } \\
\text { Preamble }\end{array}$ & $\begin{array}{l}\text { - opening educational system to new autonomous structure } \\
\text { including CCAA diversity and specific characteristics like } \\
\text { language as part of a common cultural heritage } \\
\text { - education, a decisive element in overcoming social stereotypes } \\
\text { related to the construction and use of language }\end{array}$ \\
\hline Preliminary Title & $\begin{array}{l}\text { 4. government responsibility for fixing objective criteria for } \\
\text { minimum education within limits of no more than } 55 \% \text { of school } \\
\text { hours for CCAA with their own official language and } 65 \% \text { for } \\
\text { those without }\end{array}$ \\
\hline $\begin{array}{l}\text { Title I General } \\
\text { Teaching Rules } \\
\text { Chapter I Early } \\
\text { education }\end{array}$ & $\begin{array}{l}\text { 9. first manifestations of communication and language as an } \\
\text { element to be developed in the first cycle } \\
\text { learning to use language in the second cycle }\end{array}$ \\
\hline $\begin{array}{l}\text { Chapter II Primary } \\
\text { education }\end{array}$ & $\begin{array}{l}\text { 13. contribution to the development of student capacity in } \\
\text { - appropriately use castellan and the official language of the } \\
\text { CCAA } \\
\text { - understand and express simple messages in a foreign language } \\
\text { 14. subject areas at this level include: } \\
\text { - Castellan and CCAA official language and literature } \\
\text { - foreign languages }\end{array}$ \\
\hline $\begin{array}{l}\text { Title II Special } \\
\text { Teaching Rules } \\
\text { Chapter II Teaching } \\
\text { Languages }\end{array}$ & $\begin{array}{l}\text { 50. aspects of language teaching in Official Language Schools } \\
\text { - language teaching structure, related academics, and degrees } \\
\text { - encouraging study of European and co-official languages } \\
\text { - } \quad \text { promotion of teaching languages online }\end{array}$ \\
\hline
\end{tabular}




\begin{tabular}{|c|c|}
\hline $\begin{array}{l}\text { LAW: } 1995 \\
\text { LOPEG }\end{array}$ & no language references \\
\hline $\begin{array}{l}L A W: 2006 \\
L O E \\
\text { Title I Teaching and } \\
\text { its Distribution } \\
\text { Chapter I Early } \\
\text { years education }\end{array}$ & $\begin{array}{l}\text { 14. Distribution and pedagogical principles } \\
\text { - both cycles: development of communication and language } \\
\text { - second cycle: first move toward learning a foreign language, } \\
\text { especially last year, as well as starting to read and write, early } \\
\text { initiation experiences in information and communication } \\
\text { technologies, visual and musical expression. }\end{array}$ \\
\hline $\begin{array}{l}\text { Chapter II Primary } \\
\text { education }\end{array}$ & $\begin{array}{l}\text { 18. Organization - areas in this stage include } \\
\text { - castellan language and literature, the co-official language and } \\
\text { literature if it exists, and a foreign language } \\
\text { - possible addition of the second foreign language in the third } \\
\text { cycle of this stage }\end{array}$ \\
\hline $\begin{array}{l}\text { Chapter VII } \\
\text { Teaching languages }\end{array}$ & $\begin{array}{l}\text { 59. Organization } \\
\text { - basic, intermediate, and advanced language levels } \\
\text { - carrying out approved tests to obtain official certification of } \\
\text { knowledge of the languages studied }\end{array}$ \\
\hline $\begin{array}{l}\text { Title III Teaching } \\
\text { staff } \\
\text { Chapter III Teacher } \\
\text { training }\end{array}$ & $\begin{array}{l}\text { 102. educational administrations promote foreign language training } \\
\text { for all teachers }\end{array}$ \\
\hline $\begin{array}{l}\text { Chapter IV Faculty } \\
\text { recognition, } \\
\text { support, and } \\
\text { assessment }\end{array}$ & $\begin{array}{l}\text { 105. recognition of teachers' work teaching their subject in a } \\
\text { foreign language in bilingual centres }\end{array}$ \\
\hline $\begin{array}{l}\text { Title VIII. } \\
\text { Economic resources }\end{array}$ & $\begin{array}{l}\text { 157. establishment of programs to reinforce the learning of foreign } \\
\text { languages }\end{array}$ \\
\hline $\begin{array}{l}\text { LAW: } 2013 \\
\text { LOMCE } \\
\text { Preamble XII }\end{array}$ & $\begin{array}{l}\text { prioritizing and incorporating command of a second or third } \\
\text { foreign language, following EU's promotion of multilingualism }\end{array}$ \\
\hline $\begin{array}{l}\text { Title I General } \\
\text { teaching rules } \\
\text { Chapter I Early } \\
\text { Years Education }\end{array}$ & $\begin{array}{l}\text { 14. government sets minimum objectives, competences, content, } \\
\text { and evaluation criteria for language education with } 55 \% \text { for CCAA } \\
\text { with a co-official language and } 65 \% \text { for those without }\end{array}$ \\
\hline
\end{tabular}




\begin{tabular}{|c|c|}
\hline $\begin{array}{l}\text { Chapter II Primary } \\
\text { education }\end{array}$ & $\begin{array}{l}\text { 18. Primary education organized into global and inclusive areas in } \\
\text { six courses requiring courses in: } \\
\text { - Castellan language and literature } \\
\text { - a foreign language and at least one block of specific subjects } \\
\text { including a second foreign language } \\
\text { - co-official language and literature in CCAA with one, treating } \\
\text { it like Castellan } \\
\text { 19. Castellan or co-official language used as a support in the foreign } \\
\text { language learning process where oral comprehension and } \\
\text { expression are prioritized and flexibility for teaching and assessing } \\
\text { acquisition in students with disabilities is taken into account when } \\
\text { grading, or exempting }\end{array}$ \\
\hline $\begin{array}{l}\text { Chapter VII } \\
\text { Language teaching }\end{array}$ & $\begin{array}{l}\text { 59. defines aims of language teaching as training students in proper } \\
\text { use of languages outside the educational system with basic, } \\
\text { intermediate, and advanced levels corresponding to the Common } \\
\text { European Framework of Reference for Languages (CEFR) levels } \\
\text { A, B and C, subdivided into A1, A2, B1, B2, C1 and C } 2 \text { where the } \\
\text { basic level is determined by educational administration }\end{array}$ \\
\hline $\begin{array}{l}\text { Additional provision } \\
38\end{array}$ & $\begin{array}{l}\text { legally protecting Castellan and co-official languages } \\
\text { - guaranteeing students' rights to receive the teaching in } \\
\text { Castellan other co-official languages in their respective } \\
\text { territories where Castellan is the vehicular language of } \\
\text { education as are the co-official languages in the respective } \\
\text { CCAA } \\
\text { - requiring students to understand and express themselves, } \\
\text { orally and in writing, in Castellan and, where appropriate, in } \\
\text { the corresponding co-official language } \\
\text { - not discriminating when using the Castellan or co-official } \\
\text { languages in teaching } \\
\text { criterion guarantees of the right to receive education in } \\
\text { Castellan and the co-official language in CCAA having both } \\
\text { - Language and Literature in these languages will be taught in } \\
\text { the corresponding languages educational administrations may } \\
\text { determine reasonable proportions for teaching non-linguistic } \\
\text { subjects in these languages, with the possibility of integrating } \\
\text { foreign languages } \\
\text { establish non-linguistic subjects taught exclusively in } \\
\text { Castellan, a co-official or foreign language, provided there is a } \\
\text { publicly funded alternative offer for each language; if no } \\
\text { teaching offer with Castellan as the vehicular language, the } \\
\text { Ministry of Education, Culture and Sports (MEC), fully, } \\
\text { exceptionally, assumes schooling expenses in private centres } \\
\text { where offers exist, expiring with the adoption of measures to } \\
\text { guarantee these linguistic rights } \\
\text { CCAA with legally protected non-official languages offer } \\
\text { them in the free autonomic configuration subject block }\end{array}$ \\
\hline 39 & Final evaluation of the co-official language and literature \\
\hline
\end{tabular}




\begin{tabular}{|c|c|}
\hline & $\begin{array}{l}\text { - calculation of grade in same proportion as Castellan language } \\
\text { and literature where students exempt from taking this subject } \\
\text { are exempt from tests }\end{array}$ \\
\hline $\begin{array}{l}\text { LAW: } 2020 \\
\text { LOMLOE } \\
\text { Title I General } \\
\text { Teaching Rules } \\
\text { Chapter III } \\
\text { Curriculum and } \\
\text { distribution of } \\
\text { competences }\end{array}$ & $\begin{array}{l}\text { 6. recovery being minimum teaching of } 55 \% \text { school hours for } \\
\text { CCAA with a co-official language and } 65 \% \text { for those without } \\
\text { 14. educational administrations will promote age-appropriate } \\
\text { potential in all language development and modes of perception, } \\
\text { respecting childhood culture as in the Convention on the Rights of } \\
\text { the Child's where, without being a requirement to enter primary, a } \\
\text { first approach to reading and writing... will be favoured } \\
\text { 18. subjects for this stage: } \\
\text { - Castellan language and literature } \\
\text { - co-official language and literature if there is } \\
\text { - foreign language } \\
\text { - a second, other co-official language or transversal subject } \\
\text { 19. dedicated time for reading mastery in educational projects of } \\
\text { centres via diverse media, technology and languages and relying on } \\
\text { family and volunteer collaboration as well as exchanges of good } \\
\text { practice } \\
\text { reference to special education students and comprehension of } \\
\text { foreign language }\end{array}$ \\
\hline $\begin{array}{l}\text { Title V } \\
\text { Participation, } \\
\text { autonomy, and } \\
\text { governance of } \\
\text { centres } \\
\text { Chapter II } \\
\text { Autonomy of } \\
\text { centres }\end{array}$ & $\begin{array}{l}\text { 121. centres should adopt and include measures to compensate for } \\
\text { gaps that may exist in communication competence in Castellan and } \\
\text { co-official language, if it exists }\end{array}$ \\
\hline Additional provision & $\begin{array}{l}\text { educational administrations should apply verification, analysis, and } \\
\text { control instruments for analyses to guarantee all students achieve } \\
\text { linguistic communication competence in Castellan and the co- } \\
\text { official language where appropriate, adopting measures to } \\
\text { compensate for possible gaps given these adjustments } \\
\text { - Castellan and the co-official language considered vehicular } \\
\text { language in accordance with the applicable regulations } \\
\text { - offering co-official languages that do not have that character } \\
\text { in all their territory }\end{array}$ \\
\hline
\end{tabular}

\section{DISCUSSION}

While the publication dates of the IB Programme Standards and Practices (PSP) documents (2014; 2018) could warrant a look at Spanish legislation only in force during that same time, the many changes in Spanish educational legislation over time have impacted on its current state. Therefore, some steps back in time will necessarily be taken as the comparisons are drawn. 


\subsection{IB PROGRAMME STANDARDS AND PRACTICES 2014}

In the 2014 version, there are two practices that must be in place for authorization. Practice B1.5 and its corresponding requirement B1.5a calling for the development and implementation of policies and procedures that support the PYP, concretely an IB expectations consistent language policy. Fundamental concepts that drive IB expectations include inquiry, collaboration, reflection, evaluation, constructivism, critical thinking, differentiation, holistic and authentic learning, international mindedness, plurilingualism, concept-based learning and transdisciplinarity. Although the mention of the exchange of good practice in Article 19 of the 2020 LOMLOE could comprise all these fundamental concepts, links are found explicitly to collaboration, plurilingualism, as well as evaluation and to some extent transdisciplinarity.

\subsubsection{Collaboration}

The expectation of Spaniards participating more in education as per the 1985 LODE could be seen as a step toward collaboration on one level whereas the transfer of some educational policy responsibilities from the national level to CCAA in the 1990 LOGSE could be seen as first steps in collaboration at this other level. Article 63 also in LOGSE mentions the move toward policies reinforcing collaborative opportunities to reduce inequalities in schools. The redefinition of participation of educational communities in school governance in the 1995 LOPEG supports further collaborations. The $2006 \mathrm{LOE}$ promoted the importance of collaboration by linking it to the provision of quality education. This collaboration went on to include student participation. Educational policy collaboration between national government and CCAA was furthered in Articles 1 and 7, extending this to include local businesses and focussing on cooperation and coordination in these efforts. Lastly, collaboration is specifically addressed in Article 19 of the 2020 LOMLOE in the use of families and volunteers to support reading mastery. Unfortunately practice C1.8 "Collaborative planning and reflection recognizes that all teachers are responsible for language development of students" (I.B., 2014, p.10). which would have to be in place for the visit after authorization, does not have explicit supports in relation to this sort of collaboration.

\subsubsection{Plurilingualism}

Plurilingualism and the Section A practice requiring students to learn a language in addition to the language of instruction are supported by Spanish legislation in the many references to student capacity in and learning of Castellan, CCAA co-official languages, European languages, and foreign languages. These references include: 1990 LOGSE Articles 13, 14, 50, 121; 2006 LOE Articles 14, 18, 59, 102; 2013 LOMCE Articles 14, 18, 19, 59; and 2020 LOMLOE Articles 6, 14, 18, 19, as well as Additional provision 38. Because many of Spain's regions have co-official languages, those schools by IB standards would not be required to offer an additional one, although in most cases a third one is offered. Although requirement A7b supporting mother tongue and host country language learning is not required at the time of authorization, it would have to be in place for the following evaluation visit where these same supports would be valid in meeting it.

\subsubsection{Evaluation}

Although there are several references to evaluation and testing, specific links to these as fundamental elements of the IB would have to be looked at more in-depth. In the Preliminary Title 4 of the 1990 LOGSE, setting objective criteria is one important step in the evaluation process. Inspection and supervision go hand in hand when evaluating schools and the 1995 LOPEG 
regulated education authorities' control over this. Relative to this the 2006 LOE proposed establishing mechanisms of evaluation to make all educational areas accountable and defining the purpose of education in Article 140 as a way of guiding educational policy. Specifically related to languages, Article 59 expected approved tests to be carried out in the teaching of language to obtain official language certification. Although this was for official language centres and older students, the practices of testing and language certification at the primary level are a reality. The 2013 LOMCE perceives the use of external exams as diagnostic measures to improve administrative policies. More specifically, Article 14 specifies government responsibility for setting evaluation criteria for the second cycle of Early Childhood education; Article 19 addresses flexibility in assessing language acquisition in students with disabilities; and the 39th Additional provision gives specific guidance on the final evaluation of the co-official language, grade calculations, and exemptions. In the 2020 LOMLOE Article 121 note the need to adopt and include measures to compensate for gaps in Castellan and co-official language communication competence. This is further supported in the 38th Additional provision where educational administrations should use control instruments, verification, and analysis to guarantee achievement these competencies, applicable regulations are used to identify these as vehicular languages, mentioning the possibility of offering co-official languages that are not seen as such in all of a region. It goes on to identify objective-related evaluation for students with learning difficulties and the replacement of the $6^{\text {th }}$ primary revalidation with a $4^{\text {th }}$ primary diagnostic test.

\subsubsection{Transdisciplinarity}

The concept of transdisciplinarity arises in two instances of the word search. First in the 2013 LOMCE Additional provision 38, where the choice to teach non-linguistic subjects in different languages demonstrates the transdisciplinarity of communication competence, and second in the mention of transversal subjects when blocking second languages in the 2020 LOMLOE. More importantly, the limits set at various points in legislation where content in $55 \%$ of school hours are available for CCAA with an official language, timetables could be designed to support a transdisciplinary curriculum.

\subsubsection{Written curriculum}

As schools move beyond authorization into evaluation when using this document, those practices in progress will need to be in place. Legislative supports for practice C2.10 where policies are to be integrated into the written curriculum would be based on aspects of curricular organization including: 1990 LOGSE Articles 9, 13, 14, 50; 2006 LOE Articles 59; 2013 LOMCE Articles 14, 18, 19, 59, Additional provision 38; and 2020 LOMLOE Article 1221 and Additional provision 38. That said, the way in which the school develops the written curriculum would have to ensure alignment in the curriculum content elements driven by the legislation but ensuring integration is evident.

\subsubsection{Taught curriculum}

For Section C3 on teaching, legislative supports for practice C3.7 where diverse student language needs are met by teaching and learning would include the articles defined under plurilingualism. Given the multiple references to backing co-official language and European language learning, schools would just need to ensure that this legislation is truly in place in a way that supports those needs. Additionally, the 2020 LOMLOE basis on Universal Design for Learning would support diverse ways of thinking based on principles of neuroscience. For practice C3.8 where all teachers are responsible for student language development, schools would have to ensure an understanding 
by the faculty that this is a shared belief. The 2006 LOE Article 102 referring to the promotion of foreign languages training for all teachers regardless of their specialty could be considered a step in the right direction.

\subsection{IB PROGRAMME STANDARDS AND PRACTICES 2018}

As the new 2018 IB Programme Standards and Practices are implemented, schools new to the PYP will be expected to adhere to these. The general standard 0301 moves beyond development, implementation, and PYP support to include communication of, review, efficacy and thriving in the creation of a school culture. As in the 2014 version, there is a language policy specific practice which also moves from IB expectation consistency to regular review, international understanding support, multiple ways of communicating, and additional language learning. This practice is further defined by requirements that specify language policy review following IB language policy guidelines, using multilingualism as a fact, right and resource when describing the school's policy, facilitating language development with a variety of resources, and seeing language learning as a shared right and responsibility that is supported by defined contextually good practices. The idea of the creation of school culture is addressed superficially in the 1990 LOGSE by opening the educational system to the diversity of CCAA comments on language as part of a common culture. Although the 2002 LOCE was not implemented, a culture of effort was mentioned which could become part of a school culture. More recently the 2020 LOMLOE Article 14 refers to the incorporation of the culture of children found in the United Nations' Convention on the Rights of the Child.

\subsubsection{Policy review}

The evaluation of educational policies is specifically mentioned in the 2006 LOE Article 1 and as part of Article 140 where the purpose of evaluation is seen as guiding educational policy. Other areas where review can be addressed as part of the evaluation process include: 1995 LOPEG Articles 19 and 29; and $2006 \mathrm{LOE}$ Articles 10, 132, and 143. This last article specifically addresses the evaluation of the educational system and carries over in the 2013 LOMCE and 2020 LOMLE. It is in the evaluation of the educational system that schools, especially led by the director as part of that post's competence, the review of policy. Schools that are part of the IB would use the IB language policy guidelines as part of that process though schools that are not part of the IB may be interested in following the guidelines in their review processes.

\subsubsection{Intercultural understanding and multilingualism}

Although supporting intercultural understanding is not addressed explicitly in Spanish legislation, the reference to language as part of CCAA cultural heritage in 1990 LOGSE and support in learning would support understanding of those cultures. Promoting command of second and third languages as part of the European Union's promotion of multilingualism would also lead to possibilities of addressing this concept. The idea of guaranteeing educational opportunities like learning languages is first found in the 1985 LODE. Reference in the 1990 LOGSE to the education in the construction and use of language to overcome social stereotypes could support multilingualism as a resource. As part of the EU, incorporation of multilingualism must be a fact which is provided in the 2013 LOMCE. Finally, the $38^{\text {th }}$ Additional provision in the 2013 LOMCE and carried over into the 2020 LOMLOE allows for the legal protection of languages in Spain where this bilingualism, and in cases of incorporating more languages, multilingualism, is guaranteed as a right. This right is established in practice where students should be able to receive 
instruction in Castellan, co-official, non-official, and foreign languages. The clause referring to non-discrimination based on languages found in previous legislation is also incorporated here.

\subsubsection{Multiple ways of communicating}

Given the recent pandemic, the importance of technology to drive our ways of communication has been imperative. References related to the use of technology include 2006 LOE Article 14 where early initiation experiences in information and communication technologies (ICT) are promoted. Other ways of expression including visual and musical are referred to in that same article. The 2020 LOMLE refers to promoting age-appropriate potential in all language development and modes of perception in that same article and in Article 19 names diverse media, technology and languages as supports for reading mastery educational projects. Reference to language learning resources is found in Article 157 of the 2006 LOE, but no other references appeared for resources in the language search. One could infer that references to supporting students with learning difficulties in the comprehension of a foreign language and curricular diversification mentioned in the 2020 LOMLOE would imply the use of a variety of resources to facilitate language development.

\subsubsection{Additional language learning-rights and responsibilities}

All the legislation mentioned in the section on plurilingualism would be valid for additional language learning. Similarly, the rights and responsibilities defined in legislation espoused in the section on intercultural understanding and multilingualism would be valid for seeing learning as a shared right and responsibility. In relation to responsibility, those detailed in the laws for educational boards, directors, and faculty would also support this requirement. The specification about students learning a language in addition to the language of instruction from at least 7 years of age which excludes further language learning if students are in programmes learning at least two has only changed from the previous Standards and Practices version by adding the term 'multilingual' to the text in describing the programme. The same links to legislation hold as those described previously.

\section{CONCLUSION}

As per the definition of policy, Spanish legislation supports schools in showing or proving their capacity to meet requirements of the IB, answering most of the questions related to policy issues, despite the many tensions that have arisen because of changes in governance. Fortunately, many of the articles that support or prove IB practices from early legislation have been carried over and improved upon in recent reforms.

While word searches addressing policy and language in Spanish legislation did not result in findings that addressed all fundamental expectations of the IB, a large portion of the requirements related to language learning and teaching that should be found in the language policy are present.

In the 2014 edition, these supports fall into the areas of: collaboration with the expected participation of school community stakeholder; plurilingualism with the many references to learning co-official, European, and foreign language; evaluation to guarantee the competency of the vehicular language as well as additional language certification; and transdisciplinarity in the teaching of nonlinguistic subjects through additional languages.

In the 2018 edition, these supports fall into the areas of: policy review as specified in the evaluation of a school's education system; intercultural understanding and multilingualism when referring to cultural heritage of language as well as the references seen for the promotion of plurilingualism in support of the 2014 edition; multiple ways of communicating with the integration of technology 
and other forms of expression; as well as specifically addressing the rights and responsibilities of language learning.

While these supports exist legislatively, it is in the hands of schools to ensure that the writing and implementation of their language policy supports these connections.

\section{FURTHER RESEARCH}

IB PYP authorization also requires the implementation of an assessment policy and at the evaluation stage, an inclusion policy. As the IB PSP 2018 version is applied, further requirements will drive the development of policies related to access/admission, academic honesty, and protection of minors. A similar look at the PSP documents and legislation may help schools in their development and implementation.

Part of the PSP requirements is seeing the connections between and across these policies. Further research is needed to show these links, especially noting that the fourth objective of the 2020 LOMLOE links knowledge policies to other equality, health, diversity, and digital rights related policies.

While national legislation has been looked at in this study, the legislation of Autonomous Communities (CCAA) and municipalities could provide further support to schools in these more specific contexts. Case studies from schools in relation to their perceptions of policy implementation in these contexts could provide further insight into their particular and shared needs. 


\section{BIBLIOGRAPHYCAL REFERENCES}

Aud, S.L. (2007). School Choice by The Numbers: The Fiscal Effect of School Choice Programs, 1990-2006. School Choice Issues in Depth. April 2007 Milton and Rose D. Friedman Foundation, Indiana, USA.

Education policy in the United States (n.d.). Ballotpedia. accessed Aug. 1, 2020. https://ballotpedia.org/Education_policy_in_the_United_States

González (2006). Estudio Económico sobre el Tratado de Ibn Abudún, el vino y los gremios en al-Andalus antes del siblo XII, Tesis doctoral, Fundación El Monte, Sevilla, 2006

International Baccalaureate Organization (2014), Programme standards and practices, Cardiff, Wales.

International Baccalaureate Organization (2018), Programme standards and practices, Cardiff, Wales.

John Dewey Project on Progressive Education. (2003). A Brief Overview of Progressive Education. Vermont: University of Vermont. accessed Aug. 1, 2020. http://www.uvm.edu/ dewey/articles/proged.html

Knight, C. (2020). The Three A's of International Schools, https://www.internationalschoolparent.com/articles/accreditation-authorization-affiliation/

Ley Orgánica 1/1990. Ordenación General del Sistema Educativo, Madrid, España, 3 de octubre de 1990.

Ley Orgánica 5/1980. Por la que se regula el Estatuto de Centro Escolar, Madrid, España, 19 de junio de 1980.

Ley Orgánica 8/1985. Reguladora del Derecho a la Educación, Madrid, España, 3 de julio de 1985.

Ley Orgánica 8/2013. Mejora de Calidad Educativa, Madrid, España, 9 de diciembre de 2013.

Ley Orgánica 9/1995. Participación, Evaluación y Gobierno, Madrid, España, 20 de noviembre de 1995.

Ley Orgánica de Educación 2/2006, Madrid, España, 3 de mayo de 2006.

Ley Orgánica por la que se modifica la Ley Orgánica 2/2006, de 3 de mayo, de Educación aprobado en la sesión del Consejo de Ministros celebrada el 3 de marzo de 2020. https://www.educacionyfp.gob.es/dam/jcr:1ef5d4e5-a41b-40a3-867b-e3b320dc48be/03loe-con-lomloe-web-2020-03-03.pdf

National Geographic. (2013). Rousseau Murió Hace 235 Años, National Geographic Historia. https://historia.nationalgeographic.com.es/a/rousseau-murio-hace-235-anos_7443 (accessed August 6, 2020) 
Policy (n.d.). In Online Etymology Dictionary. accessed Aug. 1, 2020. https://www.etymonline.com/search?q=policy

Policy (n.d.). In Oxford Dictionary Lexico. accessed Aug. 1, 2020. https://www.lexico.com/en/definition/policy,

Race to the Top. (n.d.). Ballotpedia, accessed February 27, 2014 in https://ballotpedia.org/Education_policy_in_the_United_States

Rodríguez Pardo, J.M. (2008). El alma de los brutos en el entorno del Padre Feijoo. Pentalfa Ediciones, Asturias, España.

Rychen, D. S. \& Salganik, L. H. (Eds.). (2001). Defining and Selecting Key Competencies. Göttingen, Germany: Hogrefe \& Huber

Spanish Ministry of Education and Science. (2007). School Leadership in Spain, OECD Country Background Report, www.oecd.org/edu/schoolleadership

StateUniversity.com Education Encyclopedia. (n.d.). Spain. History \& Background. accessed Aug 11, 2020. https://education.stateuniversity.com/pages/1409/Spain-HISTORY-

BACKGROUND.html\#ixzz6UobBj3cM

United States Dept of Education. (2017). The Federal Role in Education. accessed Aug. 1, 2020. https://www2.ed.gov/about/overview/fed/role.html

Warder, G. (2001-2008). Horace Mann and the Creation of the Common School. Disability History Museum. http://www.disabilitymuseum.org/dhm/edu/essay.html?id=42 (accessed August 5, 2020) 


\section{ABOUT THE AUTHORS}

\section{Veronica Steffen García}

Born and raised in rural Iowa to an immigrant Filipina mother and second-generation German/Luxembourgian father, Veronica completed her Master's degree in Spain where she married and settled. She worked as a teacher and coordinator at International College Spain (Madrid) for over 25 years, moving on as International Programmes Coordinator at the Instituto Educativo SEK (Spain) where she led Primary Years Programme (PYP) implementation in their six schools. Having successfully attained PYP Authorization, she then worked as Senior Learning and Teaching Coordinator first at the Qatar Foundation (Doha) followed by VIPKID (Beijing, China). With over 30 years of experience in education, she currently works as an independent contractor. Veronica received her Doctorate in Education with a focus on curriculum implementation in 2015 at the University of Camilo José Cela. She continues to support the International Baccalaureate (IB) organization as a workshop and visiting team leader, as well as teaching post graduate courses for the IB Educator Certificates at the University of Camilo José Cela.

Contact information: vsteffen@ucjc.edu

\section{Daniel Prieto Steffen. MSc}

Born and raised in a bilingual environment to an American mother and Spanish father, he attended an international school in Madrid, Spain where he partook in the IB Middle Years Program and the Diploma Programme. He completed his first degree in physical therapy where he experienced the implications of the relationship between the mind and the body. After that, being the creative person he is, he was recommended to work in Film. Thus, he took a dive for a career in filmmaking. Directing, producing, and writing various short films, as well as lead producing a feature film which curiously led him to contemplate the possible relationships between brain science and these different film and the completion of a Master's degree in Cognitive Neuroscience and Cellular and Molecular Neurobiology, quickly ending up in education where he was able to use these varied skills to nurture the learning of many. He is currently a PYP Coordinator in Brains International Schools - María Lombillo, in Madrid, Spain.

Contact information: dsteffen@colegiobrains.com

\section{Ángeles Bueno-Villaverde}

She is a professor at the Universidad Camilo José Cela and Coordinator of the International Baccalaureate Certificates. Master in International Education and Bilingualism. She has carried out numerous investigations: "Study on the Educational Participation of Families and Students in the Centers of the Community of Madrid", "Impact of cooperative learning on the inclusion of gifted students in the Community of Madrid" (MINECO), "Differentiated teaching for gifted students", "Teaching and learning additional languages in the International Baccalaureate in the Primary Years Program" and "Giftedness and minorities: problems and youth.". She has supervised several Doctoral Theses. 